\title{
Environmental Accounting and Corporate Sustainability: A Research Synthesis
}

\author{
Gbenga Ekundayo ${ }^{1} \&$ Festus Odhigu ${ }^{2}$ \\ ${ }^{1}$ Department of Administrative and Financial Sciences, Oman College of Management and Technology, Oman \\ ${ }^{2}$ Department of Management Studies, Middle East College, Oman \\ Correspondence: Gbenga Ekundayo, Department of Administrative and Financial Sciences, Oman. E-mail: \\ gbenga.ekundayo@omancollege.edu.om \& festus@mec.edu.om
}

Received: August 5, 2020

doi:10.5539/ijbm.v16n1p1
Accepted: November 6, 2020

Online Published: December 1, 2020

\begin{abstract}
The paper examined the extent of environmental accounting and its relationship with corporate sustainability with an ardent focus on controversies, contradictions, gaps and relationships with previous explorations. The researchers adopted an assiduous literature review approach on the diverse perspectives of investigators and scholars through probing into their conceptualizations, empiricism and theoretical underpinnings of industrialized nations, emerging economies and least developed countries. The analysis provides a comprehensive overview of recent studies on multiple dimensions of environmental accounting and their interrelationship with corporate sustainability. We observed that there was a broad gap on the issue of profitability, financial leverage, industry type and social and moral responsibility of environmental accounting.
\end{abstract}

Additionally, we also discovered that the relationship between environmental accounting and corporate sustainability has not been effectively established in emerging economies. Premised on this intriguing findings, it was recommended that standard setters should yield to the incessant calls and proposals canvassed by renowned scholars for directives bordering on the establishment of International Financial Reporting Standards (IFRS) on environmental accounting (EA) in order to enhance corporate sustainability (CS).

Keywords: environmental accounting, corporate sustainability, stakeholder theory

\section{Introduction}

The paradigm shift of evolving economic activities in many areas from agriculture to manufacturing occasioned by the industrial revolution of the late $18^{\text {th }}$ century have brought about increasing use of natural resources and continuous emissions of greenhouse gases by industries around the world especially in this age and has inevitably brought issues on the nexus between environmental accounting (EA) and corporate sustainability (CS) interrelationships to the front burner of environmental management and green accounting discourses and has raised overwhelming calls for an upward surge in the strength of exploration in contemporary times. The industrial revolutions led to tremendous economic improvement for most spectrum of people in the industrialized societies. Besides the ubiquitously dynamic nature of globalization, the environmental constraints imposed on corporations and the quest for appropriate practices to disclose environmental information has necessitated the need to drive for EA to be brought to the fore to resolve issues relating to EA. The incessant short comings of environmental pollution, oil spillage, gas flaring, global warming, deforestation, depletion of natural resources, bio diversity and environmental degradation has necessitated the fundamental problem of the current human society which is very severe (Amiri et al., 2014.).

The issues of environmental accounting (EA) is associated with both developing and developed nations and it is a vast and scintillating issue that has aroused the attention of authorities and scholars on the debates and emerging strands of literature. it would have been presumed that studies on environmental accounting (EA) is overarching and the issues surrounding it should have been over flogged, but it happens not to be the situation because, it is not a static event, but a dynamic and ever revolving process. Diverse literatures have proxied environmental accounting (EA) as Bartolomeo et al (2000) views it as a superset of accounting, Okafor (2018), assessed it as the fusion of environmental dimension into the macro or micro level.

However, the increase in fostering global environmental awareness and the campaign for sustainable economic 
development is redirecting the attention of organizations towards environmental sensitivity. Sustainable development as is generally known, focuses on the creation of wealth and prosperity, whilst considering the true importance of social and environmental aspects, allowing businesses and public organizations to meet triple bottom line mandates in sustainable management.

The vibrancy for sustainability and its nomenclature has assumed giant strides in diverse fields such as, environmental microbiology, environmental ecotoxicology, environmental law, water supply engineering, solid waste management, environmental economics, environmental entrepreneurship, environmental management accounting (EMA) and environmental financial accounting (EFA) by bringing together scholarship and practice in a highly organized and logical manner. This approach is of relative immense importance and there is a wide spread belief, that it will provide a hard core methodological basis for establishing issues related to sustainable development, but not solving them, because they are by nature unresolvable. Remarkable differences could also exist among developing and developed countries studies based on the strength of their Environmental Accounting (EA) and Corporate Sustainability (CS) domain which could be as a result of their research settings, dispositions, and the peculiarity of the environment wherein the study is carried out.

Retrospectively, there has been a proliferation of substantial empirical and theoretical studies on this topical issue which were researched by erudite scholars such as (Hernadi \& Bettini, 2012; Kilian \& Hennings; 2014, Kumar, 2017; Schaltegger \& Wagner, 2006), relating to environmental accounting (EA) of corporate entities which had their dominance in developed countries which could be at variance with studies in developing countries as a result of their legal and regulatory framework. In the context of developing countries, researchers such as (Beredugo \& Mefor; 2012; Ironkwe \& Success; 2017; Okoye \& Ezejiofor, 2013), studied environmental accounting (EA) and corporate sustainability (CS). These studies had their divergent perspectives of outcomes of the link between environmental accounting (EA) and corporate sustainability (CS) which appear to have been inconclusive and failed to reach a consensus on the intrinsic relationship between environmental accounting (EA) and corporate sustainability (CS). Their research findings had negated the consensus proposition of the bidirectional causality between environmental accounting (EA) and corporate sustainability (CS). Furthermore, most of these studies have been concentrated on selected sub-sectors of the developing countries economy which may not be a true representation of the activities of the entire business sector.

The paper seeks to address new frontiers and fill the void in previous studies by exploring possible distinctive links between environmental accounting (EA) and corporate sustainability (CS) literature by buttressing on critical issues bordering on this contentious and controversial sub facet of accounting. This study will also take a further step by addressing the following pertinent question: What are the factors that drive environmental accounting (EA) and corporate sustainability (CS)?

The rest of this paper is demarcated into the following subtitles : section 2, deals with the concept of environmental accounting (EA)and corporate sustainability (CS), section 3, gives an insight into the theoretical framework on which this study was hinged and further establishes its assertions based on this contemporary issue, section 4 rhetorically, presents prior empirical evidence on environmental accounting (EA) and corporate sustainability (CS), while section 5 , which finalizes the report, is based on conclusion and recommendations.

\section{Literature Review}

\subsection{Concept of Environmental Accounting}

Environmental Protection Agency (1995) defined environmental accounting as the identification and measurement of the costs of environmental materials and activities using this information for environmental management decisions accruable to shareholders.

According to Osemene (2010), environmental accounting reports vital information on the use of natural resources, communication and measurement of the costs of business activities and their potential impact on the environment.

Howes (2002), views that environmental accounting has a connection between diverse subsets of accounting such as external and internal environmental accounting and it also fuses together organizations culture and environmental sustainability to give it a more balanced view.

We report, however, that environmental accounting is the incorporation of environmental and social issues to already established financial information, with the ultimate aim of satisfying stakeholder's aspirations.

\subsection{Concept of Corporate Sustainability}

$\mathrm{Yu}$ and Zhao, (2015), posits that corporate sustainability (CS) is an all-encompassing notion that inculcates environmental responsibility, economic viability and social responsibility. 
Montel (2008), reports it as being all inclusive and embraces economic standard, social and environmental contexts. Fifka and Drabble (2012), views it as evolving and dynamic reporting practices of businesses over a course of time.

From the submission of this present study, we therefore document it as the structure and activity that absorbs economically, socially and environmentally over time.

\section{Theoretical Framework of Environmental Accounting (EA) and Corporate Sustainability (CS)}

\subsection{Stakeholder Theory}

Enormous amount of verifiable studies and anecdotal reports/evidence have demonstrated the validity of the stakeholders theory in the analyses of the relationship between environmental accounting (EA) and corporate sustainability (CS) and are visible testaments to the fact that stakeholders theory only exists in the context of a firm and it also corroborates the view of other academic discourses that are firmly rooted and championed along this course. Some of the positions and assertions canvassed by multiple authorities, advocates and reputed scholars in the field of green accounting will be fully established in order to anchor the study and debates on this pertinent issue. The pioneer philosopher of stakeholders theory is Freeman (1984).Stakeholders theory was founded on the premise that corporations are an integral part of a social system with a pivotal focus revolving around the various stakeholders groups drawn from the ranks of society. Vast amount of theoretical and empirical studies have demonstrated the validity of the stakeholders theory in the analyses of the relationship between company's employees, customers, suppliers, financiers, communities, governmental bodies, political groups, trade associations, due to their impact on companies and have affirmed that the theory holds sway due to its inclination with research on firmament (Donaldson \& Preston, 1995). Also, there have been dissenters to these propositions based on this theory, due to the conflicting and contrasting academic literature and stand points. Sternberg (1997) refutes the claim, that entities can be held accountable to a collective group of stakeholders and asserts that, the imperative position of those in the managerial cadre is to reach a compromise on balancing the discords of various stakeholders, given the enormous number of stakeholders and their discords. Therefore, based on this theory and drawing inspirations from the work of Robert (1992), we will therefore hinge this research on stakeholder theory due to its precedence and fulcrum on studies related to environmental accounting (EA) and corporate sustainability (CS).

\section{Prior Empirical Evidence on Environmental Accounting (EA) and Corporate Sustainability (CS)}

A wide array of exhaustive studies exploring environmental accounting (EA) and corporate Sustainability (CS) on companies in both developed and developing countries have been investigated by multiple scholars and their findings have been mixed. We therefore present a case by case scenario of each of these studies by indicating and embedding their objectives, methodologies adopted, multidimensional findings and core arguments raised in certain situations as have been portrayed in previous studies which informed the field.

Robbins (1991) investigates the environmental constraints imposed within industrial company's strategies within the context of U.S.A and the European countries, where there was an exponential increase in the disclosure of environmental information. He probed to know, if such disclosures were as a result of environmental damages and their expected financial impact. The study deduced that environmental impacts has a significant effect on asset and business values. He equally reveals, companies violations of environmental laws and dysfunctional ways of disposing industrial waste as the rationale for environmental pollution. This follows the school of thought and is a statement of fact, based on the proposition that findings from America and Europe context are not in consonance with the fallacy of generalization.

Schaltegger and Wagner (2006) presents an empirical analysis of managing sustainability performance measurement and reporting in an integrated manner. A cursory observation demonstrates that there is a link between sustainability Balanced score card as a strategic information and management approach, sustainability reporting as a supporting measurement approach and sustainability reporting for communication and reporting .

Enahoro (2009) examines the level of independence of tracking of costs impacting on the environment; level of efficiency and appropriateness of environmental costs and disclosure reporting. Pearson's product moment correlation tests-tests statistics, multivariate linear regression analysis were used as the statistical tool of analyses. The result shows that, there is a deficiency in the costing system used for tracking of externality costs. Furthermore, environmental operating expenditures are not charged independently of other expenditures.

Figuero, Orihuela and Calfucara (2010) studies the relationship between green accounting and sustainability of Peruvian companies. It is observed that there is an overestimated GDP traditional measure by $51-64 \%$, which is the real economic income produced by Peruvian metal mining sector during the period 1992-1996. 
Cortez and Cudia (2011) explores the impact of environmental innovations on financial performance of Japanese electronics companies following the growing literature linking corporate social performance with profitability. The sample consists of 10 automotive and 10 electronic companies listed in the Tokyo Stock Exchange. Granger causality tests were performed to establish virtuous cycles. Their findings were in consonance with risk minimization efforts of electronics companies in spite of declining profitability.

Khalid, Lord \& Dixon (2012), examines the level of environmental management accounting (EMA) implementation in Malaysian companies. It was discovered that the elements of environmental related management accounting within some of the organizations was driven by a motivation to reduce costs rather than environmental conservation.

Beredugo and Mefor (2012) investigates the relationship between environmental accounting, reporting and sustainable development in Nigeria. Pearson correlation coefficient and OLS were used for the statistical analysis, the results revealed that there is a significant relationship between environmental accounting, reporting and sustainable development. It was found that Environmental Accounting (EA) motivates organizations to monitor their GHG emissions and other environmental data against reduction targets, and also non-compliance with environmental accounting and reporting regulations has its adverse effects. From Environmental Accounting (EA) and Corporate Disclosure (CD) perspectives, the factors that are of utmost importance are (1) profitability, (2) financial leverage (3) regulatory pressure (4) social and moral responsibility, (5) legal and cultural factors, (6) independent audit, (7) company size, and (8) industry type. More in depth and standardized measures should be taken into paramount consideration in establishing the statistical criteria and also to provide a basis for differentiation between various dimensions and degrees of Environmental Accounting (EA) and Corporate Sustainability (CS).

Hernádi and Bettini (2012) indicates that companies have a pivotal role in achieving sustainability. Their current activities not only have an effect on today's world but also on the future as well. Now, companies themselves are slowly understanding this; but few know how to achieve corporate sustainability. However, traditional accounting systems do not deal with accounting for social and environmental effort and cannot demonstrate them. For this reason, sustainability accounting has gone a step ahead of green accounting and should be thoroughly emphasized by researchers/investigators and the underlying concerned parties. Recommendations were rife that this decisions, must be based on the pertinent information provided by sustainability accounting that invariably contributes to economic, social and environmental perspectives. Following the systematic sequence of this study, it is apparent that statistical tools were not taken into consideration. Retrospectively, the narratives imply a high level of compulsion.

Okoye and Ezejiofor (2013) studies the appraisal of sustainability environmental accounting in enhancing corporate performance and economic growth in Nigeria. Pearson Product Moment Correlation Co-efficient was used as the basis of analysis. The findings show that sustainable environmental accounting has significant impact on corporate productivity.

Kilian and Hennings (2014) studies the relationship between corporate social responsibility and environmental accounting in German controversial industries. A sample of 30 German DAX companies for a period of 11years between the year (1998 -2009) spanning across subsectors such as consumer goods, financial services, chemical and pharmaceutical, automobiles, financial services, transportation, time, energy, manufacturing, consumer goods, and tourism were taken into perspective. The authors used a combination of qualitative and quantitative approach. The result of the duo reveals/ indicates a coherent transition from the qualitative study to a category system, that encompasses both CSR philosophies and CSR related activities as the normative basis of CSR communication.

Agbiogwu, Ihendinihu and Okafor (2016) examines the impact of environmental and social costs on performance of Nigerian companies comprising net profit margin, earnings per share and return on capital employed. The study was carried out on a sample of 10 randomly selected firms in Nigeria for the period 2014. The researchers employed $\mathrm{T}$ test for the empirical investigation and found that the sample companies environmental and social cost significantly affects net profit margin, earnings per share and return on capital employed of manufacturing companies. The authors recommended that government should mandate manufacturing companies to adhere strictly to environmental laws.

Kumar (2017) explores the link between environmental accounting and triple bottom line, quantitative environmental reporting and standard method, voluntary environmental disclosure and legal requirement, size of company and volume of environmental disclosure, material flow analysis and life cycle assessment to achieve sustainable development by using a sample of Bangladeshi companies. Paired sample test, cross tabulation, matrix were the statistical tool deployed for the analyses. The findings revealed that sustainability of corporations was 
associated with the performance of economic, social and environment. Other factors like quantitative environmental reporting, standard method, voluntary environmental disclosure, legal requirement, size of the company, volume of environmental disclosure, material flow analysis, and life cycle assessment were found that, they worked as a complement to enhance the performance of economic, social and environment to achieve sustainable development in Bangladeshi corporation.

Ironkwe and Success (2017) presents an empirical examination on environmental accounting and sustainable development. The study focuses on the Niger Delta area of Nigeria, using spearman's rank correlation and chisquare to analyse the bidirectional relationship between economic stability, sustainable development and environmental accounting, their study reveals that environmental accounting is imperative for sustainable development in Nigeria and should be absorbed by all companies which fall within the purview of the Niger Delta domain of Nigeria.

Giang, Binh, Thuy,Ha and Loan(2020) examines Environmental Accounting (EA) for Sustainable Development (SD) in Vietnamese companies. The samples cut across 80 companies such as mining, manufacturing, and processing industries. Data is analysed using multivariate linear regression. Research results, reveals that determinants such as managers perceptions of costs and benefits, environmental changes, characteristics of the scale of production and business activities of enterprises, pressures to announce sustainable environmental information and reporting have significant influences on the development of environmental accounting for sustainable development.

Drawing from the empirical literature on Environmental Accounting (EA) and Corporate Sustainability (CS), it can be inferred that most of the scholarly studies on this topical issue have been concentrated in industrialized nations and there are insufficient studies still carried out on developing countries and emerging markets on this dynamic and ever evolving issue on Corporate Reporting (CR), even though, there are circumstantial evidences of dissipation of wasteful energy.

\section{Conclusion and Recommendations}

In the foregoing sections, we have cross examined the empirical investigations, conceptualizations and theoretical antecedents of vast amount of studies dwelling on Environmental Accounting (EA) and Corporate Sustainability (CS). The precursory discloses that explorations on Environmental Accounting (EA) and Corporate Sustainability (CS) cannot be waived aside, due to the resultant effects, which impinges on entities. Mandatory obligations should be made in letter and spirit for entities to account for their substantial environmental costs, environmental liabilities, water effluent discharges, environmental pollution, and greenhouse gas emissions that cut across diverse subsectors and also to ameliorate the multiplier effects, which could jeopardize their operational capabilities. Holistic policy measures and mandated documentations on Environmental Impact Assessment (EIA) should be institutionalized by corporations in developing countries and emerging markets and made imperative in order not to circumvent and violate the environmental laws.

Furthermore, it should be used as a reference point by companies and strict enforcement to the established framework should be taken into paramount consideration. Standard setters should yield to the incessant calls and proposals made for the establishment of International Financial Reporting Standards (IFRS) on Environmental Accounting (EA) in order to enhance Corporate Sustainability (CS). Penultimately, Environmental Accounting is a subject of different theories, which may have resulted in the mixed results in extant literature between Environmental Accounting (EA) dimensions and corporate sustainability (CS). These inconsistencies call for future scientific inquiry that should be subjected to further investigation. Ultimately, with the research gap on the issue of profitability, financial leverage, industry type and social and moral responsibility, an empirical investigation incorporating these dimensions of environmental accounting will no doubt contribute significantly to the repository of knowledge on the nexus between Environmental Accounting (EA) and Corporate Sustainability (CS). Paramountly, this research was bedevilled of pertinent data on environmental accounting. Sophisticated analytical data incorporating structural equation modelling can be brought to the fore in future research on the interplay between environmental accounting and corporate sustainability in Sub Sahara Africa in order to be able to predict certain variables.

\section{References}

Agbiogwu, A. A., Ihendinihu J. U., \& Okafor, M. C. (2016). Impact of environmental and social costs on performance of Nigerian manufacturing companies. International Journal of Economics and Finance, 8(9), 173-180. https://doi.org/10.5539/ijef.v8n9p173 
Amiri, N., Panah, S. B., \& Ardeshir. (2014). Environmental accounting. International Journal of Economics, Management and Social Sciences, 3(7), 382-385. https://doi.org/10.1016/j.jclepro.2020.120891

Bartolomeo, M., Bennett, M., Bouma, J. J., Heydkamp, P., James, P., \& Wolters, P. (2000). Environmental management accounting in Europe: Current practice and future potential. European Accounting Review, 9(1), 31-52. https://doi.org/10.1080/09638

Beredugo, S. B., \& Mefor, I. P. (2012). The impact of environmental accounting and reporting on sustainable development in Nigeria. Research Journal of Finance and Accounting, 3(7), 55-62. https://doi.org/10.7176/RJFA

Cortez, M. A., \& Cudia, C. P. (2011). The impact of environmental innovation on financial performance. Journal of International Business Research, 9(Special Issue 1), 33-46. https://doi.org/10.28992/ijsam.v3i2.78

Donaldson, T., \& Preston, L. E. (1995). The stakeholder theory of the corporation. The Academy of Management review, 20(1), 65-91.

Enahoro, J. A. (2009). Design and bases of environmental accounting in oil \&gas and manufacturing sectors in Nigeria PhD Thesis. Convenant University.

Environmental Protection Agency. (1995). An Introduction to Environmental Accounting as a Business Management Tool: Key Concepts and Terms. United States Environmental Protection Agency.

Fifka, S., \& Drabble, M. (2012). Focus and standardization of sustainability reporting. Business Strategy and the Environment Journal, 21(7), 34-45.

Figueroa, B. E., Orihuela, R. C., \& Calfucura, T. E. (2010). Green accounting and sustainability of the Peruvian metal mining sector. Resources Policy, 35(3), 156-167. https://doi.org/10.1016/j.resourp

Freeman, R. (1984). Strategic Management: A Stakeholder Approach. Pitman, Boston.

Giang, N. P., Binh, Q. P., Thuy, L. T. T., Ha, D. N., \& Loan, C. H. (2020). Environmental accounting for sustainable development. Management Science Letters, 10, 1613-1622.

Hernádi, \& Bettin. (2012). Green accounting for corporate sustainability. Club of economics in Miskolc TMP, 8(2), 23-30.

Howes, R. (2002). Environmental Cost Accounting: An Introduction and Practical Guide. London, The Chartered Institute of Management Accountants.

Ironkwe, U. I., \& Success, G. O. (2017). Environmental accounting and sustainable development. International Journal of Business and Management Invention, 6(5), 1-12.

Khalid, F. M., Lord, A. P. B. R., \& Dixon, D. K. (2012). Environmental management accounting implementation in environmentally sensitive industries in Malaysia. Paper presented at the 6th NZ Management Accounting Conference, Palmerston North, and Malaysia.

Kilian, T., \& Hennigs, N. (2014) Corporate social responsibility and environmental reporting in controversial industries. European Business Review, 26(1), 79-101. https://doi.org/10.1108/EBR-04-2013-0080

Kumar, T. (2017). Achieving sustainable development through environment accounting from the global perspective: Evidence from Bangladesh. Asian Journal of Accounting Research, 1, 45-61.

Montiel, I. (2008). Corporate social responsibility and corporate sustainability: Separate pasts. Common futures Organization and environment, 21, 245-269. https://doi.org/10.1177\%2F1086026608321329

Okafor, T. (2018). Environmental costs accounting and reporting on firm financial performance. International Journal of Finance and Accounting, 7(1), 1- 6. https://doi.org/10.5923/j.ijfa.20180701.01

Okoye, P. V. C., \& Ezejiofor, R. A. (2013). An appraisal of sustainability environmental accounting in enhancing corporate productivity and economic performance. International Journal of Advanced Research, 1(8), 685693. Retrieved from http://www.journalijar.com/

Osemene, O. F. (2010). Environmental accounting in the management of small and medium scale enterprises in Oyo State, Nigeria. An unpublished PhD thesis submitted to University of Ilorin, Nigeria.

Robbins, N. (1991). Environmental auditing-a tool whose time has come. Multinational Business, 2, 20-21.

Roberts, R. (1992). Determinants of corporate social responsibility disclosure: An application of stakeholder theory. Journal of Accounting, Organisation and Society, 17(6), 595-612. 
Schalteger, S., \& Wagner, M. (2006). Integrative management of sustainability performance. International Journal of Accounting, Auditing and Performance Evaluation, 3(1), 1-19. https://doi.org/10.1504/IJAAPE.2006.010098

Sternberg, E. (1997). The defects of stakeholder theory. Scholarly Research Theory Papers, 5(1), 3-10.

Yu, M., \& Zhao, R. (2015). Sustainability and firm valuation: An international investigation. International Journal of Accounting and Information, 23(3), 289-307. https://doi.org/10.1108/IJAIM-07-2014-0050

\section{Copyrights}

Copyright for this article is retained by the author(s), with first publication rights granted to the journal.

This is an open-access article distributed under the terms and conditions of the Creative Commons Attribution license (http://creativecommons.org/licenses/by/4.0/). 